\title{
TURNING THE TIDE OF ANTIMICROBIAL RESISTANCE: EUROPE SHOWS THE WAY
}

\author{
D L Monnet (dominiquel.monet@ecdc.europa.eu)1, K G Kristinsson² \\ 1. Scientific Advice Unit, European Centre for Disease Prevention and Control, Stockholm, Sweden \\ 2. Landspitali University Hospital and University of Iceland, Reykjavik, Iceland
}

Ten years ago, European officials, experts and other stakeholders met in Copenhagen, Denmark, at the invitation of the Danish Ministry of Health and the Danish Ministry of Food, Agriculture and Fisheries. This European conference on "The Microbial Threat" due to antimicrobial resistance resulted in the publication of "Copenhagen Recommendations" calling for action to limit the emerging problem of antimicrobial-resistant microorganisms [1]. Following the conference, the European Commission prepared a comprehensive Community strategy against antimicrobial resistance, which was published in 2001 [2] and presented in Eurosurveillance [3]. Later the same year, European Union (EU) Health Ministers adopted a Council Recommendation on the prudent use of antimicrobial agents in human medicine with a series of specific measures aimed at containing the spread of antimicrobial resistance by prudent use of antimicrobial agents [4].

A review article published in this journal in 2001 showed that only six European countries had a national action plan to contain antimicrobial resistance [5]. An evaluation of implementation of the Council Recommendation performed by the European Commission showed that, by 2003, 16 countries had developed a national strategy to contain antimicrobial resistance and nine countries had an action plan [6,7]. The European Commission is currently performing another evaluation of the implementation of the Council Recommendation and its results will be available in 2009 .

Historically, Denmark was the first European country to report on the control of methicillin-resistant Staphylococcus aureus (MRSA), which took place at the end of the 1960s and in the 1970s. Although the interventions were never fully documented, this decrease in the percentage of MRSA in S. aureus blood isolates from more than $30 \%$ to less than $1 \%$ - a figure that still holds today - has been attributed to a more prudent use of antbiotics combined with increased awareness of hospital hygiene [8]. In Iceland, a public media campaign on the prudent use of antibiotics in children in the mid-1990s led to a change in parents' attitudes, to a reduction in antimicrobial use and, subsequently, to a decrease in the incidence of penicillin-non-susceptible Streptococcus pneumoniae which had increased rapidly at the beginning of the decade [9]. This issue of Eurosurveillance is the first of two special issues on antimicrobial resistance and focuses on the recent successes of several EU Member States in reverting trends in antimicrobial resistance or, for the Netherlands, in maintaining already low antimicrobial resistance rates.
Among the six countries reporting in this issue of Eurosurveillance, the French success is remarkable because this country, which had the highest outpatient antibiotic consumption per capita in the EU, has been able to reduce this consumption by $16 \%$ between 2000 and 2006 following repeated annual public awareness campaigns on the prudent use of antibiotics combined with interventions targeted at general practitioners, including academic detailing and promotion of rapid testing for Streptococcus pyogenes tonsillitis [10]. This decrease in antibiotic use combined with the introduction of the 7-valent protein conjugated pneumococcal vaccine for young children in 2002 resulted in reverting trends in penicillin resistance in S. pneumoniae [10]. Additionally, several data sources confirm a decrease in the incidence and the prevalence of MRSA. For example, data from the European Antimicrobial Resistance Surveillance System (EARSS) show a decrease in the proportion of MRSA in $S$. aureus from blood cultures from France, from 33\% in 2001 to $26 \%$ in 2007 [11]. This decrease has been attributed to the gradual expansion of infection control structures as well as implementation of specific MRSA control measures in French hospitals [10]. In Belgium, national activities to contain antimicrobial resistance have been coordinated by the Belgian Antibiotic Policy Coordination Committee (BAPCOC) since 1999. Yearly public awareness campaigns on antibiotics since 2000 have resulted in a 32\% decrease in antibiotic consumption when expressed in packages and a concomitant decrease in, e.g. macrolide resistance in S. pneumoniae and $S$. pyogenes [12]. However, France and Belgium remain among the European countries with the highest consumption of antibiotics per capita and have therefore decided to continue organising national public awareness campaigns each year to consolidate their progress towards prudent use of antibiotics.

Other European countries with much lower levels of antimicrobial consumption and resistance have shown success with their national actions on prudent use of antibiotics and infection control. Through repeated reports in the media and the introduction of rapid diagnostic tests, Slovenia was able to show a $20 \%$ decrease in antibiotic consumption in outpatients, although this decrease has so far not been followed by a concomitant decrease in resistance. In Slovenian healthcare facilities, the introduction of a comprehensive national strategy for MRSA control resulted in a decrease in the proportion of MRSA in S. aureus from blood cultures from $21 \%$ in 2000 to $8 \%$ in 2007 [13]. In the Czech Republic, an education programme targeted at primary care paediatricians, including repeated audits of 
prescribing practices and feedback, was implemented in 2001 as a control measure following increasing antibiotic consumption and resistance in the community in the 1990s [14]. In Sweden, national activities are coordinated by the Swedish Strategic Programme Against Antibiotic Resistance (STRAMA) and relayed at county level by a network of local STRAMA groups. Regular collaboration with national and regional media combined with local activities resulted in a $22 \%$ decrease in outpatient antibiotic consumption between 1994 and 2004 [15]. Finally, the Netherlands still have the lowest outpatient antibiotic consumption per capita in the EU as reported by European Surveillance of Antimicrobial Consumption (ESAC) [16], with antimicrobial resistance proportions that are among the lowest registered by the EARSS [11]. A Dutch Working Party on Antibiotic Policy (SWAB) was created in 1996 to ensure that the low level of antimicrobial resistance is preserved while improving the quality of antimicrobial prescriptions through the development of guidelines education and surveillance [17].

These experiences from European countries are encouraging. They show that it is possible to turn the tide of antimicrobial resistance through prudent use of antibiotics, better infection control practices and use of vaccines. The challenge is now to get all European countries take similar action. On 10 June 2008, EU Health Ministers adopted the Council Conclusions on antimicrobial resistance that reiterated their call for action to contain antimicrobial resistance and called upon Member States "to ensure that structures and resources for the implementation of the Council recommendation on the prudent use of antimicrobial agents in human medicine are in place and to continue with the implementation of specific strategies targeted towards the containment of the antimicrobial resistance" [18]. The Council also called upon the Commission and Member States "to coordinate an annual European initiative to increase awareness of the general public and veterinary and healthcare professionals about antimicrobial resistance, the prudent use of antibiotics in humans and animals and infection control practices". On 18 November 2008, the first European Antibiotic Awareness Day will be launched at the European Parliament in Strasbourg and marked in 29 European countries. This European health initiative coordinated by the European Centre for Disease Prevention and Control will in 2008 focus on increasing awareness of the general public about prudent use of antibiotics, based on the experience of a number of pioneer Member States reporting in this issue of Eurosurveillance. More information about European Antibiotic Awareness Day can be found at: http://antibiotic.ecdc. europa.eu.

\section{References}

1. Rosdahl VT, Pedersen KB (editors). The Copenhagen Recommendations. Report from the Invitational EU Conference on The Microbial Threat, Copenhagen Denmark, 9-10 September 1998. Copenhagen, Denmark: Danish Ministry of Health, and Danish Ministry of Food, Agriculture and Fisheries, 1998. Available from: http://www.im.dk/publikationer/micro98/index.htm

2. European Commission. Communication from the Commission of 20 June 2001 on a Community strategy against antimicrobial resistance. Available from: http://eur-lex.europa.eu/LexUriServ/LexUriServ.do?uri=CELEX:52001DC0333:EN: HTML

3. Bronzwaer S, Lönnroth A, Haigh R. The European community strategy against antimicrobial resistance. Euro Surveill. 2004;9(1):pii=441. Available from: http://www.eurosurveillance.org/ViewArticle.aspx?ArticleId $=441$.

4. Council of the European Union. Council Recommendation of 15 November 2001 on the prudent use of antimicrobial agents in human medicine (2002/77/EC). Official Journal of the European Communities, 2002 Feb. Available from: http://eur-lex.europa.eu/LexUriServ/LexUriServ.do?uri=0J:L:2002:034:0013:00 16:EN:PDF
5. Therre H. National policies for preventing antimicrobial resistance the situation in 17 European countries in late 2000. Euro Surveill 2001;6(1):pii=227. Available from: http://www.eurosurveillance.org/ViewArticle. aspx?ArticleId $=227$

6. European Commission. Report from the Commission of 22 December 2005 on the basis of Member States' reports on the implementation of Council Recommendation (2002/77/EC) on the prudent use of antimicrobial agents in human medicine. Available from: http://eur-lex.europa.eu/LexUriServ/ LexUriServ.do?uri=COM:2005:0684:FIN:EN:PDF

7. Werner G, Bronzwaer S. Ensuring prudent use of antimicrobials in human medicine in the European Union, 2005. Euro Surveill 2007;12(1):pii=677. Available from: http://www.eurosurveillance.org/ViewArticle.aspx?ArticleId=677.

8. DANMAP 98 - Consumption of antimicrobial agents and occurrence of antimicrobial resistance in bacteria from food animals, food and humans in Denmark. Copenhagen, Denmark: Danish Veterinary Laboratory, 1999. Available from: http://www.danmap.org/pdfFiles/Danmap_1998.pdf

9. Kristinsson KG. Modification of prescribers' behavior: the Icelandic approach. Clin Microbiol Infect 1999;5 (Suppl 4):S43-S47.

10. Anonymous. Recent trends in antimicrobial resistance among Streptococcus pneumoniae and Staphylococcus aureus isolates: the French experience. Euro Surveill. 2008;13(46):pii=19035. Available from: http://www.eurosurveillance. org/ViewArticle.aspx?ArticleId=19035

11. European Antimicrobial Resistance Surveillance System. EARSS Annual Report 2007. Bilthoven, The Netherlands: National Institute of Public Health and the Environment, 2008. ISBN: 978-90-6960-214-1. Available from: http://www.rivm. nl/earss/Images/EARSS\%202007_FINAL_tcm61-55933.pdf

12. Goossens H, Coenen S, Costers M, De Corte S, De Sutter A, Gordts B, et al. Achievements of the Belgian Antibiotic Policy Coordination Committee (BAPCOC). Euro Surveill. 2008;13(46):pii=19036. Available from: http://www. eurosurveillance.org/ViewArticle.aspx?ArticleId $=19036$

13. Čjžman M. Experiences in prevention and control of antibiotic resistance in Slovenia. Euro Surveill. 2008;13(46):pii=19038. Available from: http://www. eurosurveillance.org/ViewArticle.aspx?ArticleId=19038

14. Jindrák V, Marek J, Vaniš V, Urbaskova P, Vlček J, Janiga L, Marešová V. Improvements in antibiotic prescribing by community paediatricians in the Czech Republic. Euro Surveill. 2008;13(46):pii=19040. Available from: http:// www.eurosurveillance.org/ViewArticle.aspx?ArticleId =19040

15. Mölstad S, Cars 0, Struwe J. Strama - a Swedish working model for containment of antibiotic resistance . Euro Surveill. 2008;13(46):pii=19041. Available from http://www.eurosurveillance.org/ViewArticle.aspx?ArticleId=19041

16. European Surveillance of Antimicrobial Consumption. ESAC Yearbook 2006. Antwerp, Belgium: University of Antwerp. ISBN: 978-90-5728-094-8. Available from: http://www.esac.ua.ac. be/download.aspx? $c={ }^{\star}$ ESAC2\& $n=50036 \& c t=50033 \&$ $\mathrm{e}=50185$

17. Prins JM, Degener JE, de Neeling AJ, Gyssens IC, the SWAB board . Experiences with the Dutch Working Party on Antibiotic Policy (SWAB). Euro Surveill. 2008;13(46):pij=19037. Available from: http://www.eurosurveillance.org/ ViewArticle.aspx?ArticleId $=19037$

18. Council of the European Union. Council Conclusions on Antimicrobial Resistance (AMR). 2876th Employment, Social Policy, Health and Consumer Affairs Council meeting Luxembourg, 10 June 2008. Available from: http://www. consilium.europa.eu/ueDocs/cms_Data/docs/pressData/en/lsa/101035.pdf

This article was published on 13 November 2008.

Citation style for this article: Monnet DL, Kristinsson KG. Turning the tide of antimicrobial resistance: Europe shows the way. Euro Surveill. 2008;13(46):pii=19039. Available online: http://www.eurosurveillance.org/ViewArticle.aspx?ArticleId=19039 